\title{
Kosso (Hagenia abyssinica (Bruce) J.F.Gmel.) Genetic Resource
}

\author{
Tariku Simion* \\ South Agricultural Research institute, Arbaminch Agricultural research Center, Ethiopia
}

Submission: May 02, 2018; Published: May 22, 2018

"Corresponding author: Tariku Simion, South Agricultural Research institute, Arbaminch Agricultural research Center, Ethiopia, Email: gezutadesse@gmail.com

\begin{abstract}
Traditional knowledge is described as' accumulative body of knowledge, practice and belief, evolving by adaptive processes and handed down through generations by cultural transmission, about the relationship of living beings (including humans) with one another and with their environment'. Diverse combination of social and cultural backgrounds of the country contributed much to the existence of rich indigenous knowledge, including managing and using medicinal plants against human and livestock ailments. Kosso (Hagenia abyssinica has been used as a remedy for intestinal parasites, especially against cestodes. It has served as an anthelmintic in ruminants and also against tapeworms in humans. Besides being a source of medicine, it has also various other purposes such as construction, furniture, fuel wood, and soil fertility management. Regeneration of the species using seeds is becoming almost impossible as a result of human interference and climatic changes that usually follow deforestation. Therefore, micro propagation of this tree is an important alternative for propagation of elite genotypes.
\end{abstract}

\section{Introduction}

Plants have played a vital role in the prevention and treatment of disease since prehistoric times. People in different parts of the world depend on plant resources for their basic needs and are aware of many useful species occurring in their ecosystem. They have continuously developed their knowledge of traditional plant uses and plant resource management. Traditional knowledge is described as' accumulative body of knowledge, practice and belief, evolving by adaptive processes and handed down through generations by cultural transmission, about the relationship of living beings (including humans) with one another and with their environment'. In many countries of Africa, Asia and Latin America people depend on traditional knowledge and medicinal plants to meet some of their primary health care needs. For instance in Africa up to $80 \%$ of the population use traditional medicine for primary health care. Likewise, many Ethiopian communities are dependent on local plant resources for medicine. Ethiopia is endowed with diverse biological resources due to significant geographical diversity, which favored the formation of different habitat and vegetation zones. Diverse combination of social and cultural backgrounds of the country contributed much to the existence of rich indigenous knowledge, including managing and using medicinal plants against human and livestock ailments. More than $95 \%$ of traditional medical preparations in the Ethiopia are of plant origin. Hagenia abyssinica (Bruce) J.F. Gmel. is one of an important medicinal plants that societies relied on for generations for combating various ailments. Hagenia abyssinica is indigenous to mountain regions of eastern, central and southern Africa, mostly above $2000 \mathrm{~m}$ altitude. It is found in the Democratic Republic of Congo, Sudan, Ethiopia, Malawi, Zambia, Zimbabwe. Kenya, Tanzania, Uganda, Burundi and Rwanda. In Ethiopia this species occurs in the Juniper-Hagenia forests of the Simien and Bale Mountains, a forest type found only in Ethiopia. $H$. abyssinica is a multi-purpose wind pollinated and wind dispersed broadleaved dioecious tree in the plant family of Rosaceae. It has been used as a remedy for intestinal parasites, especially against cestodes. It has served as an anthelmintic in ruminants and also against tapeworms in humans. Besides being a source of medicine, it has also various other purposes such as construction, furniture, fuel wood, and soil fertility management. Recently, this species is one of the most endangered tree species due to the high demand for its timber. Regeneration of the species using seeds is becoming almost impossible as a result of human interference and climatic changes that usually follow deforestation. Therefore, micro propagation of this tree is an important alternative for propagation of elite genotypes. Tree improvement by conventional breeding is a slow process because of the long juvenile period and high heterozygosity of trees. In vitro clonal propagation of trees is an attractive alternative for obtaining high number of elite genotypes. However, somaclonal variation of the micro propagated 
elite genotypes can be a potential draw back. On the other hand, stable somaclonal variations of specific type may be advantageous for improvement of certain traits.

\section{Crop Profile}

1. Family: Rosaceae

2. Genus: Hagenia

3. Species: H. abyssinica (Bruce) J.F.Gmel.

4. Scientific name: Hagenia abyssinica (Bruce) J.F.Gmel.

5. Chromosome number: Not available

6. Ploidy level: Not available

7. Genome size: Not available

\section{Center of Origin}

Hagenia abyssinica (Bruce) J.F.Gmel. is native to Eritrea, Ethiopia, Sudan, Uganda, Kenya, Congo-Kinshasa, Rwanda, Burundi, Tanzania, Zambia and Malawi and exotic to India. It occurs in montane forests, especially in the upper forest region, at 2,300$3,300 \mathrm{~m}$. On most East African mountains, Hagenia abyssinica is common just below the tree-line (at about 3,000 meters above sea level), where it may form almost pure woodlands.

\section{Collections accessions}

Hagenia abyssinica (Bruce) J.F.Gmel. is widely distributed in montane Africa. Collection of inflorescences for medicinal purposes does not greatly affect the plants. However, in locations with high population and cattle pressure the species is now rare or has disappeared (often cut for firewood purposes). No germplasm collections are known. Living collections and other conservation measures are strongly recommended. In the southern highlands of Tanzania, Hagenia abyssinica is a protected tree. A royalty fee is required for a license to exploit it. Consequently, few trees have been planted since the mid-1980s when the laws were more strictly enforced - an unfortunate result of well-intentioned conservation laws.

\section{Economic Importance}

Hagenia abyssinica has been used in Ethiopia for centuries. It became known to European medicine as a tapeworm remedy Table 1: Common Name in Ethiopia in Various Ethnic Languages. early in the $19^{\text {th }}$ century. Before 1950 , kosso was listed as an anthelmintic in the pharmacopoeias of about 30 countries. With the advent of chemical anthelmintic with reliable dosage and action, the international use of kosso as tapeworm expellant disappeared. At present, kosso is still locally traded and used in Ethiopia where it is on sale in almost every traditional market. However, its use is rapidly diminishing. The average weight of samples of dried flowers sold in Ethiopia is about $24 \mathrm{~g}$ (considered enough for one treatment), samples usually varying between 10 $50 \mathrm{~g}$.

\section{Major Growing Area in Ethiopia}

Since it is not domesticated, there are no known specific growing areas of coverage. In general, $H$. abyssinica is a species of flowering plant native to the high elevation Afromontane regions of central and eastern Africa, with a disjunct distribution in the high mountains of East Africa from Sudan and Ethiopia in the north. It is generally found from 2000-3000m elevation, in areas receiving $1000-1500 \mathrm{~mm}$ of rainfall annually. It can be found growing in mixed afromontane forest with Podocarpus, Afrocarpus, and other trees, and in drier afromontane forests and woodlands where Hagenia is dominant, or in mixed stands of Hagenia and Juniperus procera.

\section{Production Area}

No defined area of production is available.

\section{Genetic Diversity Assessment}

\section{Molecular}

Several DNA marker systems have been developed to measure genetic diversity in plant species. Widely used PCR based marker systems are random amplified polymorphic DNA (RAPD), amplified fragment length polymorphism (AFLP), and simple sequence repeats (SSRs) or microsatellites [1]. Tileye Feyissa \& Margareta Welander [2] state that genetic diversity within and among 12 populations of the dioecious tropical tree species Hagenia abyssinica (Bruce) J.F. Gmel. in Ethiopia was examined with eight inter simple sequence repeat (ISSR) primers. A total of 104 clearly scorable bands were generated, among which 84 (81\%) were polymorphic (Table 1).

\begin{tabular}{|c|c|c|c|}
\hline No. & languages & Common name & Scientific name \\
\hline 1 & Amhara & Kosso & Hagenia abyssinica (Bruce) J.F.Gmel. \\
\hline 2 & Tigiri & Habbi & Hagenia abyssinica (Bruce) J.F.Gmel. \\
\hline 3 & Oromo & Hucha, Heto & Hagenia abyssinica (Bruce) J.F.Gmel. \\
\hline 5 & Wolyta & Kosso & Hagenia abyssinica (Bruce) J.F.Gmel. \\
\hline 7 & Hadiyya & Sut haka & Hagenia abyssinica (Bruce) J.F.Gmel. \\
\hline 8 & Kaffa & Heto & Hagenia abyssinica (Bruce) J.F.Gmel. \\
\hline 9 & Goffa & Kosso & Jaframel. \\
\hline
\end{tabular}


Agricultural Research \& Technology: Open Access Journal

\begin{tabular}{|l|c|c|c|}
\hline 10 & Gamo & Kosso & Hagenia abyssinica (Bruce) J.F.Gmel. \\
\hline 11 & Agew & Gora-gora, Shinchi & Hagenia abyssinica (Bruce) J.F.Gmel. \\
\hline 12 & English & Kousso Hagenia,Cusso,Brayera,African redwood & Hagenia abyssinica (Bruce) J.F.Gmel. \\
\hline
\end{tabular}

\section{Biochemical}

In 1870 Merck produced the first crystalline compound from Kosso, which was named "kosin". Later, it was demonstrated that kosin is an artifact generated through the alkaline extraction of the etheric crude extract of the female flowers. Several investigators proposed different structures for the active principles in Kosso. Finally Schiemenz and coworkers were able to identify the secondary metabolites in H. abyssinica and verify their structures by synthesis. The active pharmacological constituents are one-, two- and tricyclic phloroglucinol derivatives bearing isobutyryl, isovaleryl and 2-methylbutyryl sidechains, for historical reasons further named kosins. These compounds are similar to filix acid, the main constituent of Dryopteris ferns. Since the constituents are highly poisonous and hepatotoxic, the drug is now obsolete in Europe, even though Kosso shows remarkable anthelmintic activity and is still used widely in Ethiopia as taenicide. In addition to its anthelmintic activity kosins also show anti-cancer activity against murine adeno-carcinoma cell lines (MAC) in vitro and in vivo. These cell lines behave very similarly to tumors of the human colon. Furthermore, the essential oil of Hagenia was shown to exhibit weak trypanocidal activity [3-5] (Figure 1).

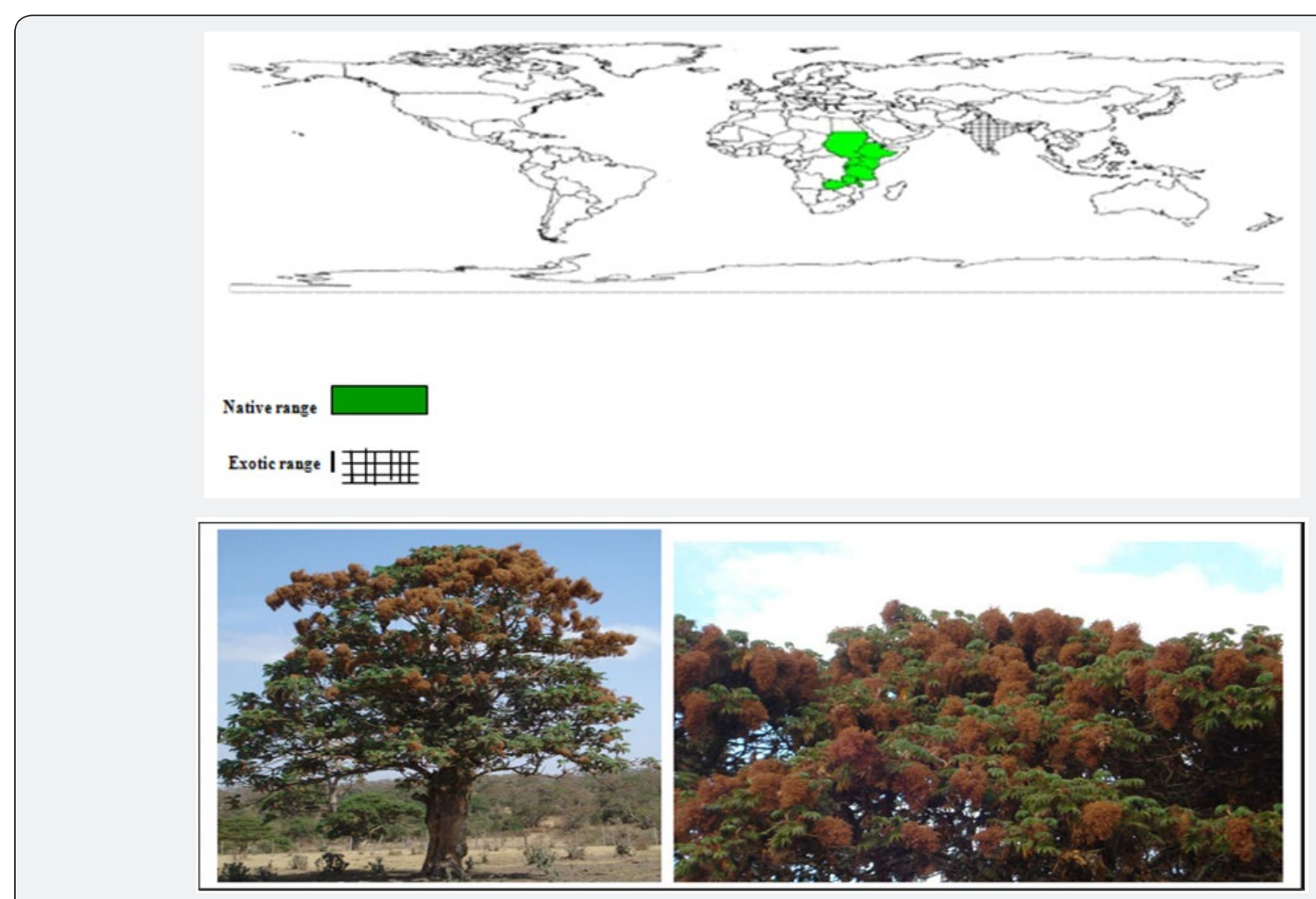

Figure 1: Standing Hagenia abyssinica tree and its flowers.

\section{Morphological botanic description}

Hagenia abyssinica is a slender tree up to $20 \mathrm{~m}$ tall, with a short trunk and thick branches; branchlets covered in silky brown hairs and ringed with leaf scars. Bark thick, brown or reddish-brown and readily peeling. No thorns or buttresses. Leaves compound, $40 \mathrm{~cm}$ long, in terminal tufts; leaflets pale or bright green above, with silvery hairs below, reddish and sticky when young, 3-6 pairs plus a terminal leaflet, each about $10 \mathrm{~cm}$ long; margin finely toothed and fringed with long hairs; leaf stalks $12 \mathrm{~cm}$ long, with expanded wings formed from the stipules, densely hairy on the underside. Flowers in handsome multibranched, terminal, drooping panicles up to $60 \mathrm{~cm}$ long and $30 \mathrm{~cm}$ wide, polygamodioecious, female heads pinkish-red, clearly veined, bulkier than the more feathery orange-buff to white male heads. Fruit small, dry, winged, asymmetric, single seeded, brown syncarp with a single more or less ovoid carpel and fragile pericarp [5-11].

Hagenia is a monospecific genus and is most closely related to the monospecific genus Leucosidea. The specific name 
means 'from Ethiopia'. Trees have either male or female flowers. Flowering and seeding can be observed throughout the year with a break in the months with the coldest temperatures.

\section{Quantitative traits}

Hagenia abyssinica is up to $20 \mathrm{~m}$ tall. Branchlets covered in silky brown hairs and ringed with leaf scars.

\section{Qualitative traits}

Hagenia abyssinica is a slender tree with a short trunk and thick branches. Bark thick, brown or reddish-brown and readily peeling. Male flowers are orange to brown or white with 12-20 stamens (male, pollen-bearing parts); female flowers are red. The flowers do not have petals, and the color is mostly due to the bracts (modified leaves). Flowers are borne in large, manyflowered, hanging groups, $30-60 \mathrm{~cm}$ long and up to $30 \mathrm{~cm}$ across.

\section{Variety Development}

Variety developed and their adaptation and mean yield: Not available

\section{Agronomic Recommendation}

In Ethiopia it is planted at the border as alive fence and no agronomic practices are used. In Tanzania, trees are planted or wildings are allowed to grow, interspersed throughout a field at a density of about 10 trees/ha. To reduce light competition with crop and foster marketable bole development, the trees are pruned once each year in November, about two months before planting crops at the onset of the rainy season. Typically, annual prunings of mature trees remove $40-50 \%$ of the canopy height. Pollarding is also a suitable silvicultural practice.

\section{Use}

\section{a. Nutritional important: Not available \\ b. Medicinal uses}

In Ethiopia the dried female flowers are traditionally used as an anthelmintic remedy, especially for tapeworm. Infections with Taenia saginata Goeze are common in this region due to the regular traditional consumption of raw beef. Historically it was one of the most famous African plants that were included in the European pharmacopoeia based on the description of a Portuguese priest in 1645 of the usage as vermifuge by Ethiopians.

In 1870 Merck produced the first crystalline compound from Kosso, which was named "kosin". Later, it was demonstrated that kosins is an artifact generated through the alkaline extraction of the etheric crude extract of the female flowers. Several investigators proposed different structures for the active principles in Kosso. The active pharmacological constituents are one-, two- and tricyclic phloroglucinol derivatives bearing isobutyryl, isovaleryl and 2-methylbutyryl sidechains, for historical reasons further named kosins. These compounds are similar to filix acid, the main Characterization of Constituents and Anthelmintic Properties of Hagenia abyssinica. Since the constituents are highly poisonous and hepatotoxic, the drug is now obsolete in Europe, even though Kosso shows remarkable anthelmintic activity and is still used widely in Ethiopia as taenicide. In addition to its anthelmintic activity kosins also show anti-cancer activity against murine adeno-carcinoma cell lines (MAC) in vitro and in vivo. These cell lines behave very similarly to tumors of the human colon. Furthermore, the essential oil of Hagenia was shown to exhibit weak trypanocidal activity. The roots are cooked with meat and the soup drunk for general illness and malaria. Bark may be pounded, added to cold water and the liquid drunk as a remedy for diarrhea and stomach-ache. Generally, this is a strong medicine that must not be taken in large quantities. Health organizations discourage the use of this infusion as the dosage cannot be controlled, and serious side-effects of over-dosage have been reported.

\section{c. Other uses}

Hagenia abyssinica is a good source of firewood, charcoal for furniture, poles, flooring, carving and cabinet. It is also used for erosion control, Trees are employed in soil-conservation activities, shade or shelter. Fire-resistant species can be used as a firebreak. Hagenia constantly sheds leaves, providing mulch and green manure. It is suitable for planting in amenity areas.

\section{Challenges}
a. Low productivity: Not available
b. Biotic stress: Not available
1. Disease: Wood is susceptible to borers.
2. Insects: Not available
3. Weeds: Not available
c. Abiotic stress
1. Drought: Not available
2. Cold: Not available
3. Salinity: Not available
4. Acidity: Not available
d. Adoption (acceptance) challenges

$H$. abyssinica is one of the endangered tree species in the country due to overexploitation. Interest towards utilizing the traditional medicine is diminishing among many especially with younger people. Despite its widespread use kosso medicine is found to be harmful to health particularly when it is taken in large quantities. Accordingly, the Forestry Law prohibits the utilization/ harvesting/of Hagenia abyssinica. The proclamation was enacted with a view of providing and enhancing better conservation, development and utilization of forests. However, in practice, there is a lack of law enforcement. Consequently H. abyssinica population is increasingly endangered. Habitat destruction reduces the existence of such important species. In spite of its significance, information on the traditional use of $H$. abyssinica has experienced little consideration. 


\section{References}

1. Gupta PK, Varshney RK (2000) The development and use of microsatellite markers for genetic analysis and plant breeding with emphasis on bread wheat. Euphytica 113(3): 163-185.

2. Tileye Feyissa, Hilde Nybom, Igor V Bartish, Margareta Welander (2007) Analysis of genetic diversity in the endangered tropical tree species Hagenia abyssinica using ISSR markers. Genetic Resources and Crop Evolution 54(5): 947-958.

3. Bekele-Tesema (2007) Useful Trees And Shrubs For Ethiopia.

4. Biruktayet Assefa, Gerhard Glatzel, Christine Buchmann (2010) Ethno medicinal uses of Hagenia abyssinica (Bruce) J.F. Gmel. among rural communities of Ethiopia. J Ethnobiol Ethnomed 11: 6-20.

5. G Abebe, LJ Dawson, G Detweiler, TA Gipson T Sahlu, et al. Hagenia abyssinica (kosso) for internal parasite control in goats. Ethiopia 2E (Kika) de la Garza Institute for Goat Research, Langston University, USA.

6. Henrieke Thomsen, Katrin Reider, Katrin Franke, Ludger A Wessjohann, Jennifer Keiser, et al. (2012) Characterization of Constituents and Anthelmintic Properties of Hagenia abyssinica. Sci Pharm 80(2): 433446.
7. MacLachlan M Eshetie, Getaneh Fentahun Tafere (2002) Manual of Highland Ethiopian Trees and Shrubs.

8. Rehman Ullah Khan, Sultan Mehmood, Saad Ullah khan, M Subhan, et al. (2013) Ethno botanical Study of Common Weed Flora of Sugarcane in District Bannu, Khyber Pakhtunkhawa, Pakistan. Journal of Medicinal Plants Studies 1(4): 49-78.

9. T. Feyissa, M Welander, L Negash (2007) Genetic stability, ex vitro rooting and gene expression studies in Hagenia abyssinica. Biologia Plantarum 51(1): 15-21.

10. Tadesse Mesfin (1996) Neglected Treasure. An Overview of Ethiopia's Vegetation.

11. Taye Bekele Ayele, Oliver Gailing, Mohammed Umer, Reiner Finkeldey (2009) Chloroplast DNA haplotype diversity and postglacial recolonization of Hagenia abyssinica (Bruce) J.F. Gmel. in Ethiopia. Plant Systematics and Evolution 280(3-4): 175-185.
This work is licensed under Creative

Commons Attribution 4.0 License

DOI: 10.19080/ARTOAJ.2018.16.555987
Your next submission with Juniper Publishers will reach you the below assets

- Quality Editorial service

- Swift Peer Review

- Reprints availability

- E-prints Service

- Manuscript Podcast for convenient understanding

- Global attainment for your research

- Manuscript accessibility in different formats

( Pdf, E-pub, Full Text, Audio)

- Unceasing customer service

Track the below URL for one-step submission https://juniperpublishers.com/online-submission.php 